\title{
Fiduciary Agreement Implementation in Car Credit Agreement on Financing Institutions of Mandiri Finance of Cirebon Based on Act No. 42 of 199 About Fiduciary
}

\begin{abstract}
Ardiansyah Alrawi ${ }^{1}$, Agus Triatmoko ${ }^{2}$ and Gunarto ${ }^{3}$
Abstract. The emergence of various institutions today's economy helped spur the economy of the community. But unfortunately the growth of the economic institutions are not supported by an adequate legal development. The presence of various financial institutions helped bring a major role in economic development of society, especially the poor. These financial institutions emerged as a form of providing funds or capital goods for the public to purchase goods on payment in installments or periodically by consumers. Construction consumer finance based on an agreement with the principle of freedom of contract as legal bases for both parties. In practice financing undertaken by financial institutions poured in the form of a credit agreement. In each of providing credit to their customers finance institutions always face a risk, therefore the customer's business situation and developments to be followed continuously starts the moment the credit is given to the loan. As for giving legal protection to the parties in the process of providing collateral (guarantee), then one of them is with the enactment of Law Fiduciary. Implementation of lending followed by a fiduciary assurance processes at financial institutions in the city of Cirebon most important is the legal effect if the Borrower defaults which are expected to creditors (financial institutions) can be easily exercised fiduciary object. Constraints faced in a fiduciary guarantee is as follows: a. Any cost of making a deed by the Borrower felt heavy, incomplete b. Any requirements of the Borrower to elaborate on the type, brand and quality of the fiduciary object, c. The office registration still limited fiduciary, fiduciary registration $\mathrm{e}$. The office could not provide information on everything about the guarantee with the issuance.

Keywords: Financing Institution, Credit Agreements, Fiduciary.
\end{abstract}

\section{Introduction}

Consumer finance is a financing model that is performed by financial companies in the form of grants for the purchase of certain products. Financial aid is defined as lending not giving money in cash for the purchase of goods and customers will only receive the goods. According Fuady, "This consumer finance credit sale because customers do not receive cash but only accept items purchased from the credit" ${ }^{4}$,

In this consumer financing system the consumer finance company providing financing in the form of loans for the purchase of an item. Then the consumer will receive funding facility for the purchase of certain goods and repay its debt or installments at regular intervals to the consumer finance company. While the seller or supplier provides the goods is paid by the consumer finance companies. In principle, not all

\footnotetext{
${ }^{1}$ Student of Master Program (S2) of Notaries Faculty of Law Universitas Islam Sultan Agung email bumbpt@yahoo.co.id

2 Students of Master of Law, Faculty of Law, Universitas Islam Sultan Agung email triatmokoagus87@yahoo.co.id

${ }^{3}$ Professor of Faculty of Law UNISSULA

${ }^{4}$ Munir Fuandy 2002 Hukum Tentang Pembiayaan Konsumen PT. Citra Aditya Bakti Bandung p 205
} 
objects can be pledged collateral banking institution or non-bank financial institutions, but the thing that can be guaranteed is the objects that meet certain conditions. The terms of the guarantee good things are: 1 . can easily help gain credit by those who need it, 2. not undermine the potential of (the power of) the credit seekers to undertake or continue his efforts, 3. provide certainty to the creditor, within the meaning of that the collateral any time available for execution, if necessary, can easily be cashed to pay off debts of the recipient (taker) credits. ${ }^{5}$

Guarantees and benefits that have accrued very important in supporting economic development. Because of the existence of this institution can provide benefits for creditors and debtors to creditors are: 1 . the establishment of security to commercial transactions covered, 2 . provide legal certainty for creditors. ${ }^{6}$

Basically the material agreements can be divided into two (2) types, namely an agreement in principal and accesoir agreement. Principal agreement is an agreement to obtain credit facilities from banking institutions or non-bank financial institutions. Accesoir agreement is an agreement that is additional and associated with the principal agreement. Examples of this agreement is an agreement accesoir loading collateral, such as mortgage agreement, mortgage, and fiduciary. So the nature of the guarantee agreement is an agreement accesoir, which follows the principal agreement. $^{7}$ Basically, according to the provisions of Article 14 paragraph (3) of Law Number 42 of 1999 on the new fiduciary Fiduciary born on the same date as the date of Fiduciary guarantee on record in the Register of Fiduciary and the lender will obtain a certificate of fiduciary entitled "For the sake of justice Based on God,"With certified fiduciary then the creditor / beneficiary of fiduciary necessarily have the right to immediate execution (parate executie), as occurs in the lending and borrowing in the banking system. The certificate equal legal force with court rulings that already have permanent legal force. In addition, for the imposition of fiduciary, Article 5 (1) Act No. 42 of 1999 on Fiduciary mandates the imposition of objects with Fiduciary made by notarial deed in Indonesian and is a Fiduciary deed. Quoting lawyer Grace P. Nugroho, SH in an article entitled Against Execution Objects Fiduciary Agreement With Hands Down Deed, ${ }^{8}$ many financial institutions (finance) and banks (commercial banks and credit) organized the financing for consumers (consumer finance), lease (leasing), factoring (factoring). They generally use a procedure that incorporates their agreement for the objects fiduciary, but ironically not made in a notary and not registered in the Register of Fiduciary to get a certificate. Such can be called a deed of fiduciary deed under the hand.

Since Act No. 42 of 1999 on Fiduciary enacted on September 30, 1999, there have been many issued rules implementing related to the registration of fiduciary Ruling Chief of Police of the Republic of Indonesia Number 8 Year 2011 on Safeguard Execution of Fiduciary, Ministry of Finance of the Republic of Indonesia Number 130 / PMK.010 / 2012 On Registration Fiduciary Company for Consumer Financing options for Motor Vehicles With Imposition Fiduciary and Government Regulation (PP) No. 21 Year 2015 regarding Registration Procedures and Fees Fiduciary Creation Deed.

\footnotetext{
${ }^{5}$ Subekti R. 1996 Jaminan-jaminan untuk Pemberian Kredit Termasuk Hak Tanggungan menurut Hukum Indonesia. Diolah kembali oleh Johannes Gunawan. Citra Aditya Bakti Bandung p. 73.

${ }^{6}$ Sri Soedewi Masjchoen Sofwan 1980 Hukum Jaminan di Indonesia Pokok-pokok Hukum dan Jaminan Perorangan BPHN Departemen Kehakiman RI Jakarta. p. 2.

${ }^{7}$ Salim HS. 2004 Perkembangan Hukum Jaminan di Indonesia Raja Grafindo Persada Jakarta p.29-30.

${ }^{8}$ Online Legal Fiduciary and period of registration the Internet accessed on 30 April 2018 at $11.00 \mathrm{am}$.
} 


\section{Research Methods}

Type of study: This study is an empirical legal research, the research done by conducting field research to obtain primary data as a source of primary power and secondary data as a complement.

Specifications Research: research is expected to provide analytical descriptive picture. This research is a descriptive meaning is expected to explain an overview of the implementation of the fiduciary agreement into practice in the car loan agreement financing institutions in the city of Cirebon. Analytical meaning of the results of this study are expected to elaborate on the findings of primary and secondary data either directly processed and analyzed in order to clarify that data categories, with systematic preparation and further discussed or examined logically. The approach method, which is used in this research is empirical juridical approach.

\section{Results And Discussion}

\subsection{Implementation Of The Fiduciary Agreement Into Practice In The Car Loan Agreement Financing Institutions In Cirebon}

These financial institutions must register fiduciary in Fiduciary Registration Office no later than 30 calendar days from the date of consumer financing agreement. These financial institutions are prohibited object withdrawal collateral in the form of motor vehicle if Fiduciary Registration Office has not issued a fiduciary guarantee certificate and handed it to the finance company. Object withdrawal collateral in the form of motor vehicles by the finance company shall comply with the requirements stipulated in the Act regarding fiduciary and agreed upon by the parties in the motor vehicle consumer financing agreement.

Finance companies who violate these provisions, subject to administrative sanctions in stages in the form of warnings, suspension of business activity, or revocation of business licenses. Facts on the field shows the financial institutions in implementing the financing include the words collateralized fiduciary. But ironically made in the notarial deed and not registered in the registration office to obtain a certificate of fiduciary. So that the deed of this kind can be called a fiduciary warranty deed under hand. In practice also often do not fiduciary registration as soon as the financing agreements / credit agreement signed by the parties. Fiduciary registered even in a long time. If the recipient of fiduciary experienced difficulties in the field so he can request police assistance for securing execution or execution can also apply to the local court. Fiduciary certificates, basically protect the receiver if the giver of fiduciary fails to meet its obligations as set forth in the agreement of both parties.

In each of providing credit to their customers finance institutions always face a risk that is not the return of the money lent to customers. Therefore the customer's business situation and developments to be followed continuously starts the moment the credit is given to the loan. He organized the data in clauses that must be included in the deed of fiduciary indirectly provides a firm grip for the creditors in particular regarding the bill which is secured, the value of collateral and how big the preferent creditors rights. The possibility of a guarantee for debt that will come must be given to accommodate the needs of the practice of the creditors. The inclusion of "results" of objects fiduciary and insurance claim automatically into the fiduciary deed could have a very favorable legal certainty and creditor in this case finance institutions. Because if 
the fiduciary object is lost or destroyed will be replaced by insurers could with similar goods or money. ${ }^{9}$ One manifestation of granting legal certainty of creditor rights is the existence of fiduciary registration agencies namely Fiduciary Registration Office. Approval procedures for implementing the credit agreement on financing institutions in the city of Cirebon in general are as follows: ${ }^{10}$

- All requests must be submitted in writing by the customer / prospective customer was signed by an authorized officer in accordance Statutes financial institutions.

- Party financing institutions researching customer request letter and perform immediate rejection if included in the criteria as follows:

- Credit requested will be used to finance the business that is prohibited by law or financial institution;

- Enterprises are classified as restricted (restricted) or high risk based on assessment of financial institutions is not worth considering;

- Companies prospective customers and or directors / shareholders included into the Joint List of Bad Debts or List Black List issued by Bank Indonesia.

- The refusal must be notified to the applicant in writing.

- If based on the data / information submitted customer / prospective customer financial institutions assess the applicant has a reputation and business prospects are good, then the financial institution will approve the proposed loan application client did a survey of prospective customers by part of credit financial institutions.

The procedure adopted fiduciary binding on financial institutions in the city of Cirebon is as follows:

- Creditors conduct a physical examination of goods to be pledged to examine the truth of quality and quantity with identification on: the number of units of goods, brands / year of manufacture / capacity / size and so on, numbers and proof of ownership / receipts and others, a storage area.

- If the data is already believed to be the truth and the truth of ownership of such goods is based on the existing evidence of ownership subsequently Fiduciary Deed made between financial institutions with the owners of the goods and their fiduciary original list and proof of ownership of goods fiduciary.

- Fiduciary Deed registration at the Registry Office fiduciary contained in the Regional Office of the Ministry of Law and Human Rights in West Java for Fiduciary Certificate issued.

Financing institutions in the implementation of the agreement Cirebon City car loans has implemented provisions of the fiduciary rules by performing the making of loans continued binding agreement with binding guarantees based on fiduciary notarial deed then register the order of issue of fiduciary certificates. Of the implementation process of lending followed by a fiduciary assurance processes at financial institutions in the city of Cirebon most important is the legal effect if the Borrower defaults which are expected to creditors (financial institutions) can be easily exercised fiduciary object

\subsection{The Obstacles Faced By Lenders In The Implementation Of Act No. 42 of 1999 On Fiduciary In Practice Implementation And Solution Fiduciary Agreement}

The obstacles faced by lenders in the implementation of Act No. 42 of 1999 on

\footnotetext{
${ }^{9}$ Interview with District Court Judge Cirebon June 212018.

${ }^{10}$ Ibid.
} 
Fiduciary in practice the implementation of the fiduciary agreement are:

The cost of making a notary and the costs related to the underwriting of fiduciary by the Borrower felt heavy, so it sometimes takes time to reach an agreement between the Debtor and Creditor (financial institutions). In Article 5 point 5 Fiduciary Law states that the imposition of the fiduciary object created by notarial deed in Indonesian and the Security Deed Fiduciary. Because deed notarized and registered means that there are additional costs that must be borne by the Borrower. Whenever there is a change regarding the matters set forth in the Certificate Fiduciary and also if the credit facility has been repaid must be implemented fiduciary deletion recording on the Register of Fiduciary (Roya) the costs are also borne by the Borrower. While costs Debtor if the Debtor is unable to settle its debts and the Borrower voluntarily gave object fiduciary for sale (executed), the provisions of Article 29, paragraph 2 of Law Fiduciary must be satisfied that the Borrower shall bear the costs of publication in at least two (2) newspapers circulating in the area concerned over the proposed sale of the object. If the Borrower does not voluntarily surrender fiduciary object to be executed so that the provisions of Article 29, paragraph la and $b$ are forced to run that implementation excecutorial title with a petition for sequestration for later public auction, then it is definitely going to add on the costs to be borne by the Borrower. Debtors generally strongly objected to the costs that must be borne in applying for a loan. According to Article 5, paragraph 2 of Law Fiduciary stated that against the deed fiduciary charged the amount of which shall be regulated further by a government regulation, while according to Article 11 of Law Fiduciary adjust the amount of the registration fee Deed of Fiduciary already established in the Indonesian Government Regulation No. 86 of 2000 on Registration Procedures and fees Making Fiduciary Deed as amended by the Indonesian Government Regulation No. 21 of 2015 regarding Registration Procedures and fees Fiduciary Creation Deed. But in practice can not be fully implemented by the Notary on cost grounds too low is not balanced with the costs Notary to prepare Fiduciary Deed.

The requirement that a complete lack of the Borrower to elaborate on the type, brand and quality of the object of fiduciary shall be described in the Deed of Fiduciary. So that the fiduciary registration to be blocked. In the explanation of Article $6 \mathrm{c}$ Law Fiduciary mention in terms of objects into an object fiduciary is an object in the inventory (inventory) that is always changing and or do not remain as stocks of raw materials, finished goods, then in the Deed of fiduciary must listed on the brand, type and quality of the object. This provision will make it difficult for providers of fiduciary, the financial institution and notaries as to describe the type, brand and quality of the fiduciary object in accordance with the provisions of Law Fiduciary not easy. Beside inefficient and ineffective.

Fiduciary registration office is still limited or not yet reached around Regency / City that are in Indonesia, making it difficult or take a long time for the financial institution as a recipient of fiduciary District / City to register, because there are only a Fiduciary Registration Office in the province.

A solution that would be given to tackling the obstacles that occur in the implementation of the fiduciary agreement into practice in the car loan agreement financing institutions in the city of Cirebon is:

- Simplify the process and the costs of making a notary and the costs related to the underwriting of fiduciary by dividing these two costs between the debtor to the creditor. 
- Prior to the manufacture of certain Deed of Fiduciary made its conditions have been met by the debtor to complete so it does not impede the process of making the Deed of Fiduciary and to the effectiveness of the time.

- Need to establish a fiduciary registration offices throughout the district / city located in Indonesia that is more effective in terms of time and speed up the process and lower the cost.

\section{Conclusion}

- Of the implementation process of lending followed by a fiduciary guarantee on the financing process in Cirebon most important is the legal effect if the Borrower defaults which are expected to creditors (financial institutions) is that it can be easily exercised fiduciary object.

- The obstacles faced by lenders in the implementation of Act No. 42 of 1999 on Fiduciary in practice the implementation of the fiduciary agreement are:

- Their cost of making a notary and the costs related to the underwriting of fiduciary by the Borrower felt heavy, so it sometimes takes time to reach an agreement between the Debtor and the Creditor.

- The requirement that the complete lack of the Borrower to elaborate on the type, brand and quality of the object of fiduciary shall be described in the Deed of Fiduciary.

- Fiduciary registration office is still limited or not yet reached around Regency / City that are in Indonesia, making it difficult or take a long time for the financial institution as a recipient of a fiduciary.

\section{Bibliography}

[1] Munir Fuandy 2002 Hukum Tentang Pembiayaan Konsumen PT. Citra Aditya Bakti Bandung.

[2] Salim HS. 2004 "Perkembangan Hukum Jaminan di Indonesia" Raja Grafindo Persada Jakarta.

[3] Sri Soedewi Masjchoen sofwan,1980 Hukum Jaminan di Indonesia Pokok-pokok Hukum dan Jaminan Perorangan BPHN Departemen Kehakiman RI Jakarta.

[4] Subekti R. 1996 Jaminan-jaminan untuk Pemberian Kredit Termasuk Hak Tanggungan menurut Hukum Indonesia. Diolah kembali oleh Johannes Gunawan. Citra Aditya Bakti Bandung.

[5] Online Legal Fiduciary and period of registration the Internet accessed on 30 April 2018 at 11.00 am.

[6] Interview with District Court Judge Cirebon June 212018. 